\title{
Productivity Improvement of Assembly Lines by Lean Methods
}

György Kovács

Institute of Logistics, University of Miskolc, Miskolc, Hungary, E-mail: altkovac@uni-miskolc.hu

In a competitive market the manufacturing companies have to produce cost effective products which can be realized by minimized production cost and higher effectiveness. The application of Lean manufacturing philosophy in order to optimize costs and quality is gaining a competitive advantage. There are lots of Lean tools which can result the improvement of the production line performance.

The article is original and unique, because beside the description of theoretical background relating to the process improvement, a practical method is also introduced in a case study.

In the study the author describes the main general steps of a Lean project completed in an industrial environment. The described case study which is a part of a real $R+D$ project shows how can be improved the efficiency and reduced manufacturing cost of a real manufacturing system by application of several Lean tools which are Onepiece flow, Takt-time analysis, Line balance and Cellular design.

Keywords: Lean production, efficiency improvement, takt-time analysis, cellular manufacturing

\section{References}

[1] WOMACK, J. P., JONES, D. T., ROOS, D. (1990). The Machine that changed the world: The story of lean production, Harper Collins Publishers. New York.

[2] HOLWEG, M. (2007). The genealogy of lean production. In: Journal of Operations Management, Vol. 25, No. 2, pp. $420-437$.

[3] FAWAZ, A. A., JAYANT, R. (2007). Analyzing the benefits of lean manufacturing and value stream mapping via simulation: A process sector case study. In: International Journal of Production Economics, Vol. 107, pp. 223236.

[4] FULlERTON, R. R., McWATTERS, C.S., FAWSON,C. (2003). An examination of the relation ships between JIT and financial performance. Journal of Operations Management, Vol. 21, No. 4, pp. 383-404.

[5] WOMACK, J. P., JONES, D. T. (1996). Lean thinking: banish waste and create wealth in your corporation, Simon $\&$ Schuster, New York.

[6] LIKER, J. K., LAMB, T. (2000). Lean manufacturing principles guide DRAFT, Version 0.5, University of Michigan

[7] KOCAKÜLÂH, M. C., BROWN, J. F. (2016). Lean manufacturing principles and its application in plastics manufacturing, http:/www.decisionsciences.org/Proceedings/ DSI2008/ docs/142-5045.pdf, downloaded: 10.10.2016.

[8] BORKOWSKI S., STASIAK-BETLEJEWSKA R., NÁPRSTKOVÁ N. (2011). The Kaizen philosophy in the aluminium products improvement. Manufacturing Technology, Vol. 11, No. 11, pp. 2-5.

[9] KOSTAL, P., VELISEK, K. (2011). Flexible manufacturing system. World Academy of Science, Engineering and Technology, Vol. 77, pp. 825-829.

[10] STASIAK-BETLEJEWSKA, R. (2012). Value engineering as the way of quality problems solving in the steel construction management. Manufacturing Technology, Vol. 12, No. 13, pp. 242-247.

[11] OSTWALD, P. F., MUÑOZ, J. (1997). Manufacturing processes and systems, 9th Edition, ISBN: 978-0-47104741-4

[12] KHOSHNEVISAN, M., BHATTACHARYA, S., SMARANDACHE, F. (2016). Optimal plant layout design for process-focused systems, https://arxiv.org/ftp/math/papers/0302/0302031.pdf, downloaded: 12.10.2016.

[13] STRAKA, M., KAČMÁRY, P., ROSOVÁ, A., YAKIMOVICH, B., KORSHUNOV A. (2016). Model of unique material flow in context with layout of manufacturing facilities. Manufacturing Technology, Vol. 16, No. 4, pp. 814-820.

[14] KORHAN, O. (2016). Facilities planning and design - IENG441, lecture notes, Department of Industrial Engineering, Eastern Mediterranean University, http://ie302.cankaya.edu.tr/uploads/files/ file/LectureNotes/IENG441\%20Facilities\%20Planning\%20and\%20Design \%20\%20Lecture\%20Notes.pdf, downloaded: 10.10.2016. 
[15] KUMIČÁKOVÁ, D., GÓRSK, F., MILECKI, A., GRAJEWSKI, D. (2013). Utilization of advanced simulation methods for solving of assembly processes automation partial tasks. Manufacturing Technology, Vol. 13, No. 4, pp. 478-486.

[16] KOVÁCS, GY. (2014). Lean production philosophy, textbook, (in Hungarian), University of Miskolc, Institute of Logistics, ISBN ISBN: 978-963-358-118-6

[17] MASSOUD, B.-L. (1999). Layout designs in cellular Manufacturing. In: Original Research Article European Journal of Operational Research, Vol. 112, No. 2, pp. 258-272.

[18] MILTENBURG, J. (2001). U-shaped production lines: A review of theory and practice. In: International Journal of Production Economics, Vol. 70, pp. 201-214.

[19] PEETU, P., KOSHY, J., BIJU, C. A. (2013). Conversion of Regular Assembly Line into Cellular Manufacturing Layout. In: International Journal of Engineering and Innovative Technology, Vol. 2, No. 7, pp. 1-9.

[20] MILTENBURG, J. (2001). One-piece flow manufacturing on U-shaped production lines: A tutorial. In: IIE Transactions, Vol. 33, pp. 303-321.

\section{Paper number: M201736}

Copyright $\odot$ 2017. Published by Manufacturing Technology. All rights reserved. 